Marquette University

e-Publications@Marquette

School of Dentistry Faculty Research and

Publications

Dentistry, School of

$1-1-2021$

\title{
In Vitro Study of Surface Alterations to Polyetheretherketone and Titanium and their Effect Upon Human Gingival Fibroblasts
}

\author{
Maryam Gheisarifar \\ Marquette University \\ Geoffrey A. Thompson \\ Marquette University, geoffrey.thompson@marquette.edu \\ Carl Drago \\ Marquette University \\ Fahimeh Tabatabaei \\ Marquette University, fahimeh.tabatabaei@marquette.edu \\ Morteza Rasoulianboroujeni \\ Marquette University
}

Follow this and additional works at: https://epublications.marquette.edu/dentistry_fac

Part of the Dentistry Commons

\section{Recommended Citation}

Gheisarifar, Maryam; Thompson, Geoffrey A.; Drago, Carl; Tabatabaei, Fahimeh; and Rasoulianboroujeni, Morteza, "In Vitro Study of Surface Alterations to Polyetheretherketone and Titanium and their Effect Upon Human Gingival Fibroblasts" (2021). School of Dentistry Faculty Research and Publications. 454. https://epublications.marquette.edu/dentistry_fac/454 
Marquette University

e-Publications@Marquette

\section{Dentistry Faculty Research and Publications/School of Dentistry}

This paper is NOT THE PUBLISHED VERSION.

Access the published version via the link in the citation below.

Journal of Prosthetic Dentistry, Vol. 125, No. 1 (January 2021): 155-164. DOI. This article is (C) Elsevier and permission has been granted for this version to appear in e-Publications@Marquette. Elsevier does not grant permission for this article to be further copied/distributed or hosted elsewhere without the express permission from Elsevier.

\section{In Vitro Study of Surface Alterations to Polyetheretherketone and Titanium and their Effect Upon Human Gingival Fibroblasts}

Maryam Gheisarifar

Graduated Resident of Prosthodontics, Marquette University School of Dentistry, Milwaukee, Wis Geoffrey A. Thompson

Associate Professor and Director, Graduate Prosthodontics, Marquette University School of Dentistry, Milwaukee, Wis

Carl Drago

Adjunct Associate Professor, Graduate Prosthodontics, Marquette University School of Dentistry, Milwaukee, Wis

Fahimeh Tabatabaei

Postdoctoral fellow, Marquette University School of Dentistry, Milwaukee, Wis

Morteza Rasoulianboroujeni

Laboratory Manager, Marquette University School of Dentistry, Milwaukee, Wis 


\section{Abstract}

\section{Statement of problem}

Soft-tissue attachment to different surfaces may play a pivotal role in the long-term success of dental implants. However, studies on the issue, especially on newer materials, are sparse.

\section{Purpose}

The purpose of this in vitro study was to evaluate the viability and adhesion of human gingival fibroblasts (HGFs) on different implant abutment materials with specific surface modifications.

\section{Material and methods}

One hundred and fifty specimens in 6 experimental groups were evaluated: smooth-machined titanium alloy (Ti), laser-modified titanium (TiL), smooth-machined polyetheretherketone (PEEK) (P), laser-modified PEEK (PL), plasma-treated PEEK (PP), laser- and plasma-treated PEEK (PLP). Machined Ti was considered as the control group. Surface roughness $\left(S_{a}\right)$, water contact angle (WCA), and X-ray photoelectron spectroscopy (XPS) were measured. HGF attachment and proliferation were observed at 1, 3, and 7 days after cell seeding. Comparison of the means among the groups was performed with 1-way analysis of variance (ANOVA) with post hoc comparison using the Tukey test $(\alpha=.05)$.

\section{Results}

$S_{a}$ values of the laser modified groups were significantly higher than those of the nonmodified (smoothmachined) groups $(P<.001)$. WCAs were significantly different among PEEK groups, and plasma-sprayed groups had the lowest WCAs. XPS analysis of both Ti and PEEK groups showed laser treatment did not have any significant effect on the surface composition of the PEEK as the same bonds with similar ratio/fraction were detected in the spectrum of the modified specimens. Scanning electron microscopy (SEM) revealed more functionally oriented HGF cells on the laser-grooved surfaces. On the first, third, and seventh day of proliferation, the titanium groups showed no significant differences $(P>.05)$. On the first and third days of proliferation, the plasma sprayed groups (PP, PLP) showed significantly greater proliferation than all experimental groups $(P<.001)$. On the seventh day of proliferation, statistically significant differences were observed between all PEEK groups and between all PEEK groups and the Ti group $(P<.001)$, with the exception of the PL and $\mathrm{P}$ groups and the PLP and Ti groups $(P>.05)$.

\section{Conclusions}

Laser-modified titanium and PEEK surfaces led to guided gingival fibroblast attachment. Plasma treatment of PEEK surfaces increased the wettability of this polymer and improved proliferation of HGF.

Clinical Implications

PEEK implant components may be a valid choice in areas of esthetic challenges where maximum softtissue contact is essential.

Dental implants are a predictable procedure for replacing missing teeth. In some instances, and particularly in sites with a thin biotype, esthetics may be challenging. Transmission of implant abutment color through overlying mucosa may occur, especially with metal implant abutments. Even with ideal biotypes, the instability of peri-implant tissues over time may lead to exposure of metal abutments or implants. ${ }^{1,2,3,4}$

Zirconia abutments are one of the restorative options available in the anterior region, and its fracture resistance and effect upon titanium implants have been studied. 5, 6,7 Significant technical and biological complications due 
to catastrophic zirconia abutment fracture have been documented. ${ }^{5}$ Foong et $a l,{ }^{5}$ in an in vitro study, demonstrated that the mean number of cycles until failure of the titanium abutment was 3 times that of the zirconia abutment; that the average load before failure for the titanium abutment was almost twice that of the zirconia abutment; and that the mode of failure of the zirconia abutments was fracture at the apical portion of the abutment without damage or plastic deformation of the abutment screw or implant. These results were consistent with those of other studies. ${ }^{5}$ Klotz et al ${ }^{6}$ and Stimmelmayr et al ${ }^{7}$ reported that for implants with zirconia abutments, the initial rate of wear and total wear after cyclic loading was greater than that with titanium abutments. According to the authors, ${ }^{6,7}$ component loosening and subsequent fracture and/or release of particulate titanium debris and damage of the internal implant connection is also a possible consequence of wear that could result in prosthetic failures.

The soft-tissue adjacent to implants may provide a protective seal between the oral environment and supporting bone. It may also prevent bacterial colonization, thus preventing irreversible marginal bone loss. ${ }^{8,9}$ Therefore, early establishment of organized soft tissue around implant abutments may be an important step toward osseointegration and long-term implant survival. ${ }^{10}$ Human gingival fibroblasts (HGFs) are the principal cells in peri-implant connective tissue ${ }^{10}$ and are important for gingival wound healing and regeneration. ${ }^{10}$ The amount and bioactivity of HGFs at the implant-gingival interface may influence formation of peri-implant soft-tissue seals. Factors involved in crestal bone remodeling include microtopography of implants, implant-abutment connections, and implant position in relation to crestal bone. ${ }^{11,12}$ It has been hypothesized that the surface characteristics of biomaterials used in implant abutments may be important for determining the quality of attachment between soft tissue and implant abutment interfaces. ${ }^{10}$

The original Brånemark protocol included smooth implant surfaces with residual periodic microgrooves made by machining bulk titanium rods. However, in the last 30 years, chemical and physical techniques have been developed to affect microtopography and improve osseointegration. ${ }^{11,12,13,14,15}$ Newer technologies such as controlled laser ablation have been used for surface modification of implant materials to improve the biologic result. Controlled laser ablation creates microgrooves on the collar surface of implants or transmucosal parts of abutments. ${ }^{15}$

The stability of peri-implant soft tissue and crestal bone levels has been reported to be the main clinical rationale for microgroove texturing. ${ }^{15,16,17,18,19,20,21}$ Resistant seals that protect peri-implant soft and hard tissues around implant transmucosal components have been of importance. ${ }^{18,22,23}$ According to in vitro and in vivo studies, wider bands of connective tissue attachment on the transmucosal parts of implants with horizontal microgrooves have been demonstrated; these physical contacts have prevented epithelial downgrowth along implant surfaces. ${ }^{24,25,26,27}$ According to a 5-year retrospective study by Guarnieri et al, ${ }^{20}$ the risk of onset of peri-implant diseases was reduced in laser-microgrooved implant collar surfaces. It was observed that connective tissue fibers oriented perpendicular to laser-microgrooved surfaces. ${ }^{20}$ Around machined implant surfaces, collagen fibers are oriented circumferentially and parallel to the surface. ${ }^{20}$

Polyetheretherketone (PEEK) is a semicrystalline linear polycyclic aromatic, thermoplastic material first developed by English scientists in $1978 .{ }^{10}$ PEEK products are processed by means of computer-aided design and computer-aided manufacturing (CAD-CAM) or pressing techniques. ${ }^{7}$

PEEK has been shown to be biocompatible, nontoxic, nonmutagenic, and not responsible for clinically significant inflammation. ${ }^{28}$ The mechanical properties of PEEK are similar to those of human cortical bone. ${ }^{10}$ Clinical use of PEEK has been limited because of its inertness. Hahnel et al ${ }^{8}$ reported that cell viability on the surface of PEEK substances was significantly lower than cell viability associated with zirconia, titanium, or polymethylmethacrylate surfaces. There are 2 main strategies for enhancing PEEK bioactivity: surface modification and composite preparation. Wettability of PEEK materials has been a critical matter in biomedicine. 
To promote wettability, different methods have been used: mechanical etching, chemical treatment, flame treatment, DC glow discharge, ion and electron beam irradiation, laser, and plasma treatment. ${ }^{29}$

Laser treatment has been shown to be an effective method of improving the surface roughness properties of different polymers. ${ }^{30}$ Plasma treatment is a common surface modification that creates oxygen-containing groups at the surface, which may improve polymer hydrophilicity. ${ }^{31}$ Surfaces with different wettability lead to different cell areas (quantity) and cell shape (quality) compared with controls. ${ }^{32,33}$ Combinations of laser and plasma treatments may provide a patterned surface composed of nanotextures and microtextures and desirable chemical groups on the surface, which can be used to modify the wetting characteristics of PEEK materials. ${ }^{31}$ Many studies ${ }^{1,17,18,19,33,34,35,36,37,38}$ have investigated the effect of different surface modifications on titanium, and with emerging technologies, there is a need for further studies. However, in vitro studies on PEEK are limited, especially in the field of implant dentistry. Surface texturing of PEEK and evaluation of biological responses to the surfaces are the novelty of the present study.

The null hypothesis was that no difference would be found between PEEK and modified PEEK surfaces and titanium and laser-modified titanium surfaces regarding surface roughness, human gingival fibroblast proliferation, and viability.

\section{Material and methods}

Six types of surface and material combination were evaluated in this in vitro study: titanium (Ti), laser-modified Ti (TiL), PEEK (P), laser-modified PEEK (PL), plasma-sprayed PEEK (PP), and laser-modified and plasma-sprayed PEEK (PLP) (Fig. 1). One hundred and fifty disks were prepared (6×25). PEEK (Invibio PEEK OPTIMA; Invibio Biomaterial Solutions) and titanium (Ti) (BioHorizons Inc) specimens were manufactured in the form of disks $(10 \times 1 \mathrm{~mm})$. Ti disks were milled from titanium alloy, Ti-6AL-4V ELI (extra-low interstitials). Laser-modified Ti exhibited 8- $\mu \mathrm{m}$ grooves (Laser-Lok; BioHorizons Inc). The machined Ti group was considered as the standard or control group.

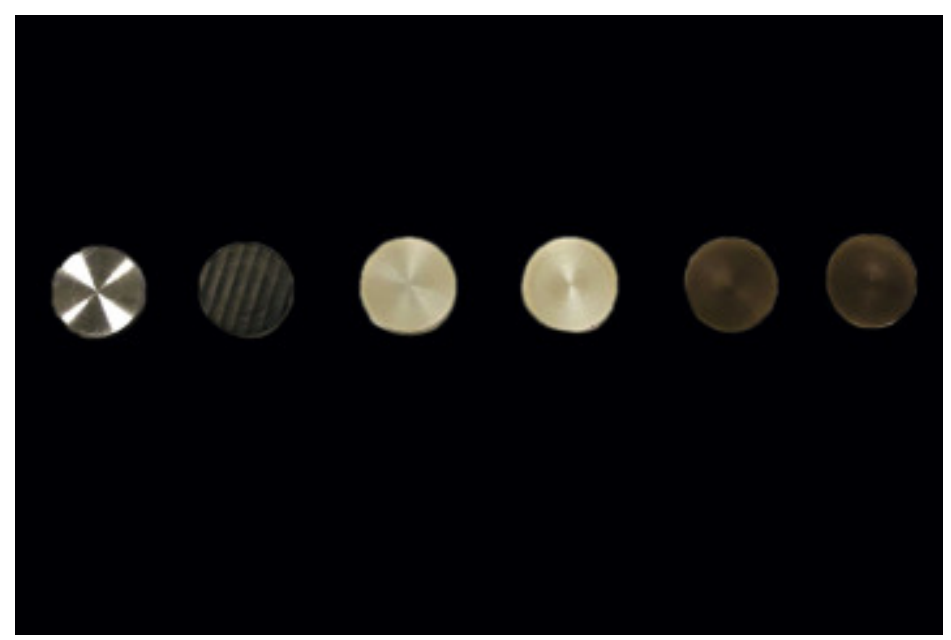

Figure 1. Experimental groups, left to right: Ti (machined Ti), TiL (Ti laser-treated), P (machined PEEK), PP (PEEK plasma-sprayed), PL (PEEK laser-treated), PLP (PEEK laser-treated and plasma-sprayed). PEEK, polyetheretherketone.

PEEK disks were machined from PEEK rods and subsequently received laser microgroove texturing (Pulse Technologies). Plasma modifications were made to 2 groups of PEEK: plasma-treated PEEK (PP) and lasermodification and plasma treatment PEEK (PLP). These substrates were modified in a commercially available plasma chamber (PE-50 Venus; Plasma Etch, Inc) equipped with a radio frequency source operating at 120 VAC 
and $60 \mathrm{~Hz}$. Nitrogen plasma treatment was carried out for 5 minutes under vacuum condition at 250 to $300 \mathrm{~W}$ and $1 \mathrm{~Pa}$ pressure.

After machining and/or surface treatment, the disks were ultrasonically cleaned and rinsed in distilled water and then dried at $50{ }^{\circ} \mathrm{C}$ for 24 hours. The disks were allocated and evaluated for physical and biological characteristics measurements as follows: 6 for surface roughness, 5 for WCA, 3 for XPS, 3 for cell attachment assays, and 8 for cell proliferation assays.

The parameters of surface characteristics were surface roughness $\left(\mathrm{S}_{\mathrm{a}}\right)$ and water contact angle (WCA). Surface roughness $\left(\mathrm{S}_{\mathrm{a}}\right)$ was evaluated using a 3D laser measuring microscope (LEXT OLS4000; Olympus). Scans were made on 6 specimens per group and 3 areas for each specimen $(500 \times 500 \mu \mathrm{m})$. WCAs were measured by using a video contact-angle measuring system at room temperature. Distilled water was dropped onto a specimen, and the water droplet was captured by using an illuminated camera (Dino-lite). The contact angle measurement was made after 10 seconds and after the droplet stabilized.

The chemical surface compositions of the machined and laser-treated specimens were analyzed with X-ray photoelectron spectroscopy (XPS). Analyses were performed with an operating angle of 45 degrees at $150 \mathrm{~W}$ to collect Auger and XPS data.

HGFs stored in liquid nitrogen were used for this project. These cells were harvested from healthy patients undergoing oral surgery with their written informed consent and with appropriate approval of the Marquette University School of Dentistry. Briefly, gingival biopsy tissues were transferred to a solution of $2 \mathrm{mg} / \mathrm{mL}$ of collagenase type I in Dulbecco modified Eagle medium (DMEM) containing 10\% fetal bovine serum (FBS) and 1\% antibiotic-antimycotic, minced well, and incubated for 4 hours at $37{ }^{\circ} \mathrm{C}$. After centrifugation of the digested tissue for 5 minutes at $200 \mathrm{~g}$, DMEM culture medium with 10\% FBS was added to the pellet, which was transferred to $25-\mathrm{cm}^{2}$ tissue culture flasks. Passages 3 to 5 of these cells were used in the present study. Cells were seeded on sterilized specimens at a density of $1 \times 10^{5}$ cells $/ \mathrm{mL}$ in 24-well plates, allowed to attach for 3 hours, and then submerged in media and incubated at $37^{\circ} \mathrm{C}, 5 \% \mathrm{CO}_{2}$, and $80 \%$ humidity for 1,3 , and 7 days.

Reagent (PrestoBlue Invitrogen; Life Technologies) was used for cell proliferation assessment. At each time point, the specimens were rinsed with PBS and submerged in the $10 \% \mathrm{v} / \mathrm{v}$ ProstoBlue in DMEM without phenolred and incubated for 2 hours at $37{ }^{\circ} \mathrm{C}, 5 \% \mathrm{CO}_{2}$, and $80 \%$ humidity to allow the reaction of the reagent with viable cells. One hundred microliters of the obtained solutions from each well was transferred to a 96-well plate, and the fluorescence intensity was measured by using a microplate reader (Synergy HTX; BioTEK) with excitation wavelengths of $540 \mathrm{~nm}$ and emission wavelengths of $590 \mathrm{~nm}$. Intensity was proportional to the number of cells on the specimen.

Twenty-four hours after seeding, the morphology and growth of the cells attached on different specimens were assessed by SEM (JSM6510 SEM; JEOL). The procedure of cell seeding was the same as mentioned previously; however, for enhanced characterization of cell morphology on the surface of different specimens, the seeding value was lowered $\left(1 \times 10^{4}\right.$ cells $\left./ \mathrm{mL}\right)$. After 24 hours of incubation, the specimens were rinsed with PBS to remove nonadherent cells, fixed for 4 hours in Karnovsky solution ( $2 \%$ glutaraldehyde $+4 \%$ paraformaldehyde), and washed twice for 5 minutes with PBS. The specimens were post-fixed for 1 hour in $1 \%$ aqueous osmium tetroxide, washed twice for 5 minutes with distilled water, and dehydrated in an increasing ethanol series: 3050-70-90-100\%. After air-drying overnight, they were sputter-coated with gold and observed by SEM.

A comparison of the means of the measured values among the groups was performed with 1-way analysis of variance (ANOVA) with post hoc comparison made by using the Tukey test $(\alpha=.05)$. A statistical software program (IBM SPSS Statistics, v24.0; IBM Corp) was used for the analysis. 


\section{Results}

The height deviation $\left(S_{a}\right)$ values of the laser-modified groups were significantly higher than those for the nonmodified (smooth-machined) groups $(P<.001)$. The WCAs of the Ti and TiL groups were not significantly different $(P>.05)$. A significant difference was found among the PEEK groups, with the plasma-treated groups (PP, PLP) having significantly lower WCAs than the other groups $(P, P L)(P<.001)$ (Fig. 2 and Table 1$)$.
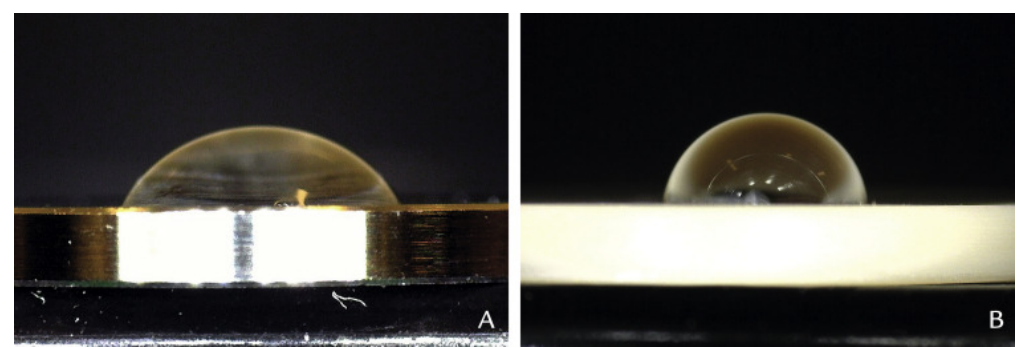

Figure 2. Water contact angle measurements. A, Titanium. B, PEEK. PEEK, polyetheretherketone.

Table 1. Surface characteristics

\begin{tabular}{|c|c|c|c|c|c|c|c|c|}
\hline $\begin{array}{l}\text { Surface } \\
\text { Characteristics o } \\
\text { Experimental } \\
\text { Materials } \\
\end{array}$ & & & & & & & & \\
\hline Parameter & $\mathbf{N}$ & $\begin{array}{l}\text { Ti, Mean } \\
\text { (SD) }\end{array}$ & $\begin{array}{l}\text { TiL, Mean } \\
\text { (SD) }\end{array}$ & $\begin{array}{l}\text { P, Mean } \\
\text { (SD) }\end{array}$ & $\begin{array}{l}\text { PL, Mean } \\
\text { (SD) }\end{array}$ & $\begin{array}{l}\text { PP, Mean } \\
\text { (SD) }\end{array}$ & $\begin{array}{l}\text { PLP, Mean } \\
\text { (SD) }\end{array}$ & $P^{* *}$ \\
\hline$S_{a}(\mu \mathrm{m})$ & 6 & $0.13^{\mathrm{A}}(0.10)$ & $2.02^{\mathrm{B}}(0.25)$ & $0.71^{\mathrm{C}}(0.24)$ & $2.52^{\mathrm{D}}(0.49)$ & $0.68^{\mathrm{C}}(0.23)$ & $2.14^{\mathrm{D}}(0.39)$ & $<.001$ \\
\hline WCA (degrees) & 5 & $54.7^{\mathrm{A}}(4.9)$ & $48.7^{A}(3.5)$ & $82.6^{\mathrm{B}}(2.2)$ & $100.2^{C}(4.6)$ & $10.4^{\mathrm{D}}(2.8)$ & $12.1^{\mathrm{D}}(2.6)$ & $<.001$ \\
\hline
\end{tabular}

P, PEEK; PL, laser-modified PEEK; PLP, laser- and plasma-modified PEEK; PP, plasma-modified PEEK; $S_{a}$, surface arithmetical mean height; $\mathrm{Ti}$, titanium; TiL, laser-modified titanium; WCA, water contact angle.

$P$ values obtained from 1-way ANOVA among materials on each parameter.

$A, B, C, D$ Tukey test groupings.

For the XPS analysis, the peaks were wider for laser-treated Ti and PEEK (rougher), as expected. The carbon (C) in the $\mathrm{Ti}$ specimens had more $\mathrm{C}-\mathrm{O}$ and $\mathrm{C}=\mathrm{O}$ bonds, and the laser-treated specimens had a higher $\mathrm{C}$ atomic percentage. $\mathrm{C}-\mathrm{C}, \mathrm{C}-\mathrm{O}$, and $\mathrm{C}=\mathrm{O}$ bonds were observed in the spectrum of untreated PEEK, as expected. Laser treatment did not seem to have a significant effect on the surface composition of the PEEK because the same bonds with similar ratio and fraction were detected in the spectrum of the modified specimen (Fig. 3). 

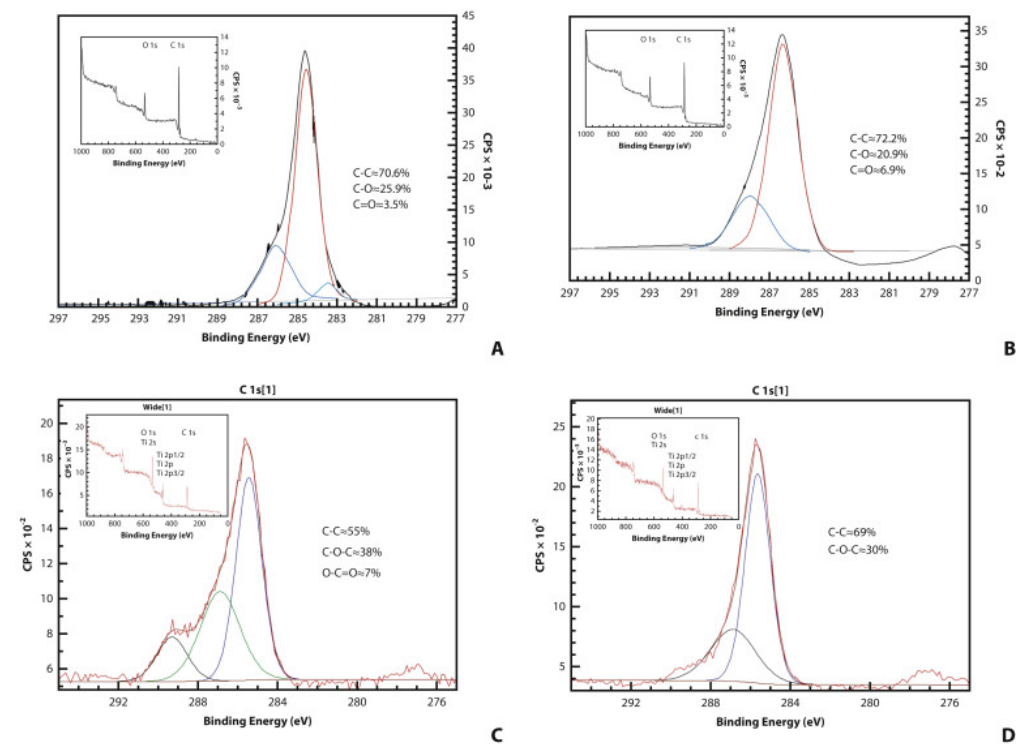

Figure 3. XPS spectra. A, PEEK. B, Laser-treated PEEK. C, Ti. D, Laser-treated Ti. Insets show elemental comparison of $\mathrm{C}$ and $\mathrm{O}$. XPS, $\mathrm{X}$-ray photoelectron spectroscopy; $\mathrm{C}$, carbon; $\mathrm{O}$, oxygen

On the first, third, and seventh day of proliferation, the titanium groups had no significant differences in cell proliferation $(P>.05)$. On the first and third day of proliferation, the plasma-treated PEEK groups showed significantly greater proliferation than all other experimental groups $(P<.001)$. On the seventh day of proliferation, statistically significant differences were observed among all PEEK groups and between all PEEK groups and the Ti group $(P<.001)$, with the exception of the PL and $P$ groups and PLP and Ti groups $(P>.05)$ (Fig. 4). 

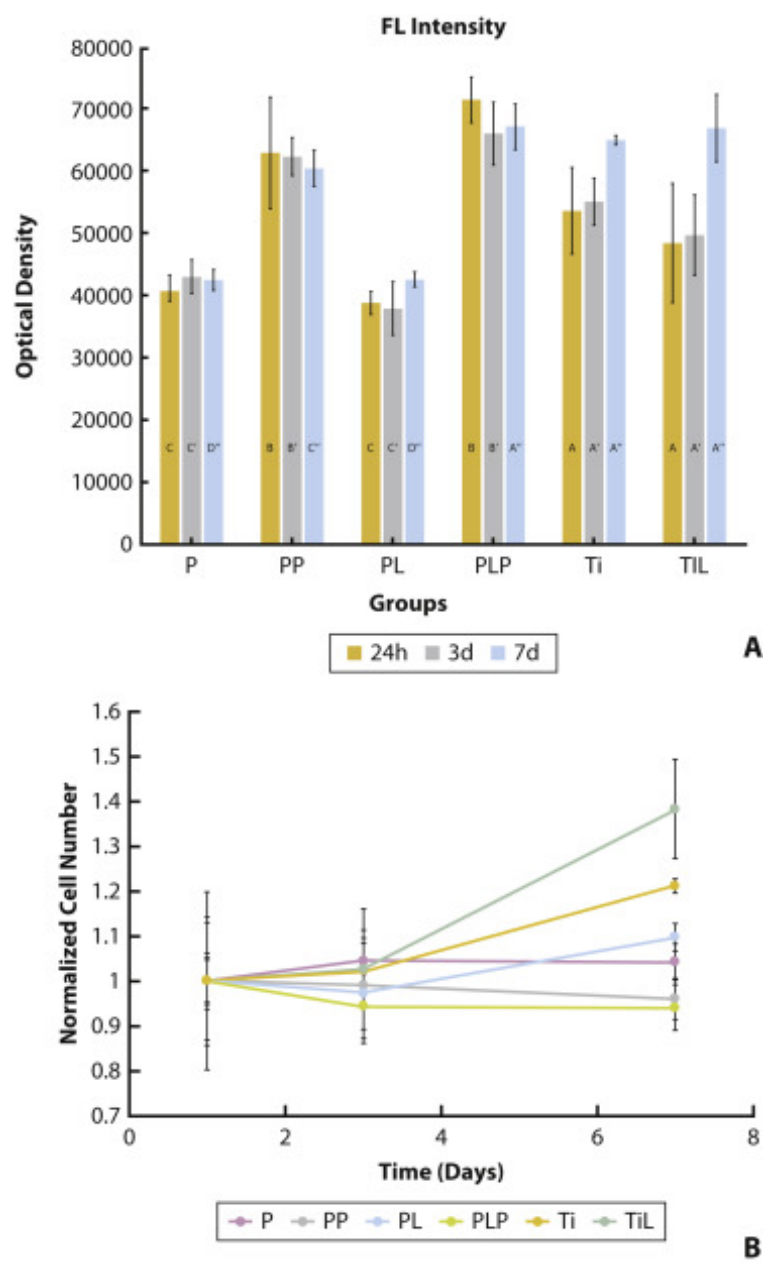

Figure 4. Fluorescence intensity. A, After 24 hours, 3 days, and 7 days. B, Normalized cell number. HGF cell proliferation of all groups. OD measurements conducted at excitation wavelength of $540 \mathrm{~nm}$ and emission wavelength of $590 \mathrm{~nm}$ for fibroblast proliferation. Labels on bar graphs (A, A', A', B, B', B", C, C', C', D, D', D") represent Tukey test groupings according to post hoc test at each measurement point. OD, optical density.

The morphologic SEM examination of the specimens showed that the laser-modified surfaces had altered surface topographies compared with the control specimens (Fig. 5). Irregular structures on the surfaces of the control groups were related to the turning process at manufacturing. The SEMs revealed more functionally oriented HGF cells on the laser-grooved surfaces; the cells in the laser-modified groups were more elongated (Fig. 6). 


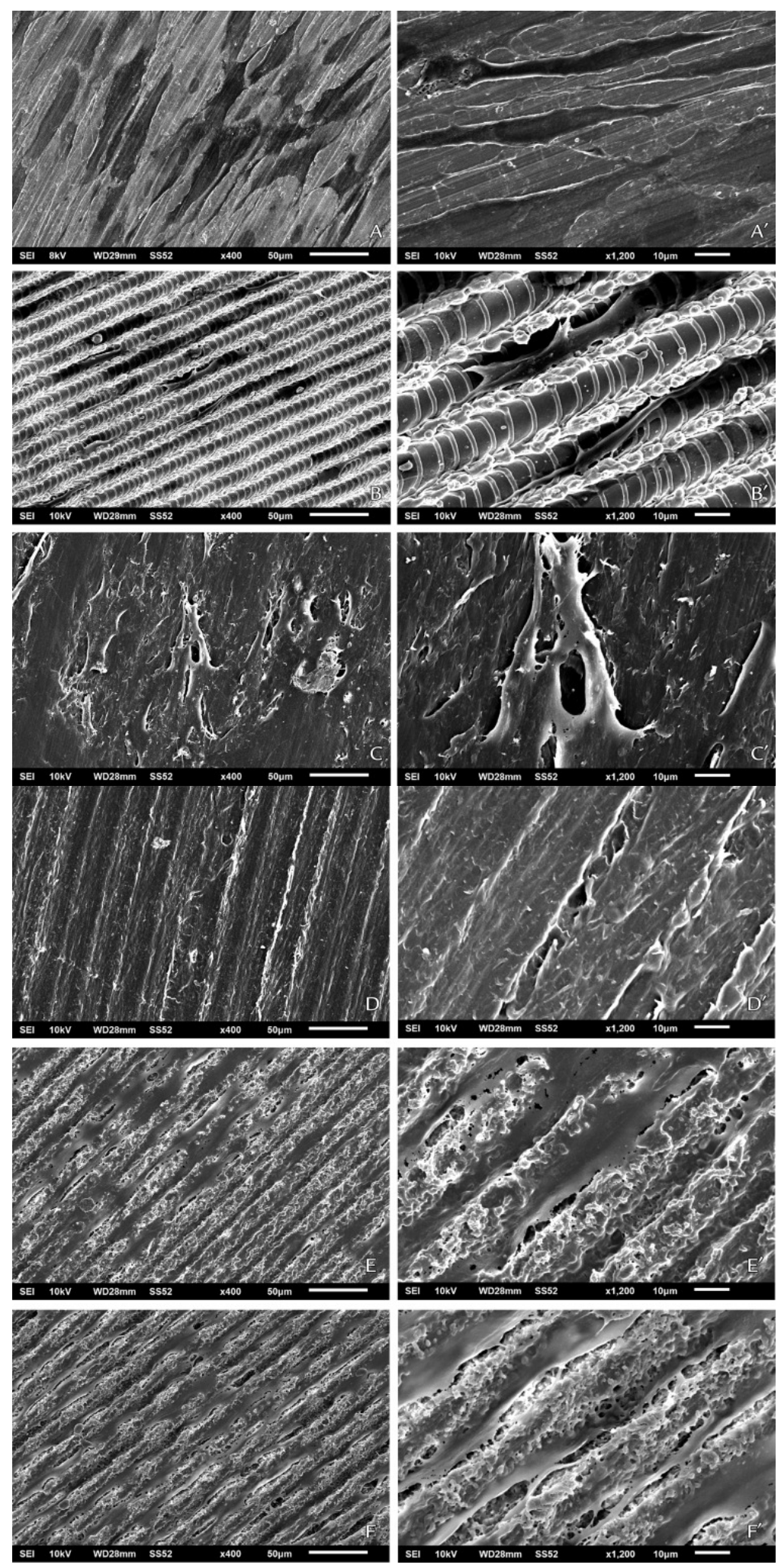

Figure 5. Scanning electron microscope images of fibroblasts attached to surfaces at $\times 400$ and $\times 1200$ original magnification. Ti group $\left(A, A^{\prime}\right)$, TiL group $\left(B, B^{\prime}\right)$, P group $\left(C, C^{\prime}\right), P P\left(D, D^{\prime}\right), P L\left(E, E^{\prime}\right)$, and PLP $\left(F, F^{\prime}\right)$. 

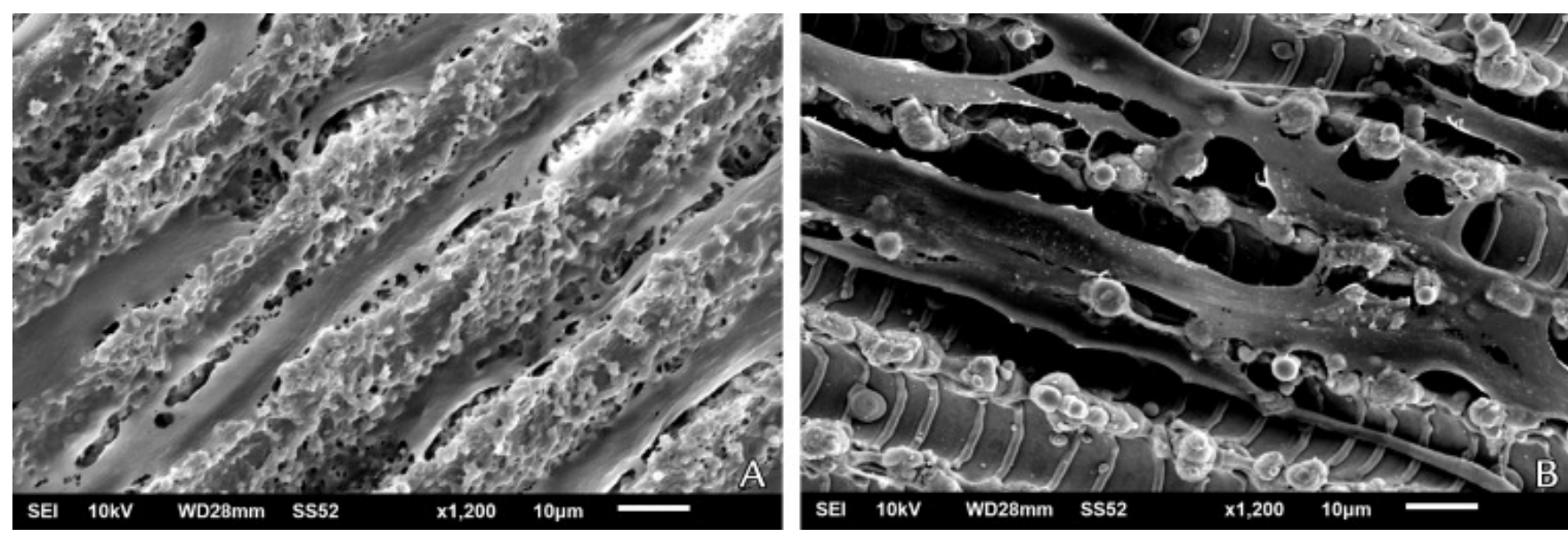

Figure 6. Scanning electron microscope images of fibroblasts attached to surface of disk. A, PLP group. B, TiL group. (Original magnification $\times 1200$ ). $P L P$, plasma-treated polyetheretherketone. TiL, laser-modified titanium.

\section{Discussion}

The purpose of this in vitro study was to compare the physical characteristics (surface roughness and WCA) and attachment and proliferation of human gingival fibroblasts on 2 implant materials with different surface modifications. The null hypothesis was rejected for both the PEEK and titanium groups. The results showed that the surface roughness of machined titanium and laser-modified titanium groups was significantly different $(P<.001)$; however, the WCAs were not significantly different $(P>.05)$. For PEEK groups, the surface roughness of the laser-treated specimens was significantly different from the that of non-laser-treated group $(P<.001)$. Plasma-treated PEEK groups in this experiment had highly hydrophilic surfaces, but all other PEEK groups had hydrophobic surfaces.

The WCAs of the Ti groups were significantly smaller than those of the P and PL groups $(P<.001)$. Both Ti and TiL groups demonstrated moderately hydrophilic properties. The results for the Ti group were consistent with those reported by Kim et al, ${ }^{1}$ who reported that the WCA for the Ti-6Al-4V alloy group was $58.5 \pm 4.9$ degrees. The slight difference between the WCAs in these 2 studies may be due to differences in specimen roughness $\left(S_{a}=0.22 \pm 0.03 \mu \mathrm{m}\right.$ for the study by Kim et al and $0.13 \pm 0.1 \mu \mathrm{m}$ for the present study). ${ }^{1}$ In the present study, plasma treatment led to ultrahydrophilic behavior of the specimens. The water droplets completely wet the plasma-treated PEEK and laser-plasma-treated PEEK specimens. On the contrary, laser textured surfaces exhibited dissimilar behavior. The contact angle on laser-treated PEEK was measured at $100.2 \pm 4.6$ degrees, which was comparable with the results of the study by Akkan et al (110 degrees). ${ }^{31}$

Different surface treatments may have dissimilar effects, and the wetting characteristics of microtextured and plasma-treated PEEK were strongly suggestive of that. When the roughness of a hydrophobic surface is increased, its nonwetting behavior improves. ${ }^{33,34}$ The results of the present study demonstrated this for the PEEK group. Besides surface topography, surface chemistry and surface energy play a role in wettability. ${ }^{1,35}$ Therefore, attributing a direct relation between surface roughness and wetting characteristics is inappropriate.

To estimate the effect of laser texturing on the surface chemistry of specimens, XPS analysis was used. Highresolution carbon 1s (C1s) analysis showed that laser treatment led to wider peaks in the specimens, which suggested rougher surfaces. It can be concluded that darker surface colors of laser-treated specimens (TiL, PL) were caused by rougher surfaces, not because of surface chemistry changes. The Ti specimens exhibited more C$\mathrm{O}$ and $\mathrm{C}=\mathrm{O}$ bonds, similar to that observed in the study by Akkan et al. ${ }^{31}$ XPS analysis of both Ti and PEEK groups 
showed that laser treatment did not alter surface chemical bonds. Although in the study by Akkan et al, ${ }^{32}$ different laser patterns were used, and PEEK seemed to show similar behavior to different laser treatments in this study. These results may be crucial for further investigation in different combinations of surface modifications on PEEK components.

Surface free energy (SFE) plays a central role in HGF cell proliferation. ${ }^{1}$ Surfaces with high SFE facilitate cell attachment by absorbing more proteins. ${ }^{1}$ Wettability and SFE are inversely related with WCA. As shown by Webb et al, ${ }^{32}$ surface wettability had more effect on cell area than cell shape. The observations in the present study confirm that. Cell proliferation was significantly different between PEEK groups (plasma treated versus nonplasma treated), with significantly different wettability. However, surface microtexture (laser treatment) influenced cell shape and morphology. In the present study, HGF cell proliferation was inversely related to WCAs, and plasma-treated groups showed the highest cell proliferations and lowest WCAs. Conversely, the $P$ and PL groups had the highest WCAs and showed significantly lower HGF proliferation $(P<.05)$. The Ti, PP, and PLP groups had higher proliferations than did the $\mathrm{P}$ and $\mathrm{PL}$ groups $(P<.05)$. Furthermore, plasma-treated groups (PP, PLP) showed significantly higher cell proliferations than Ti on the first and third days $(P<.05)$. On the seventh day, the HGF cell proliferation of Ti and PLP were not significantly different $(P>.05)$. No significant difference $(P>.05)$ in HGF cell proliferation was observed between Ti groups ( $\mathrm{Ti}$ and TiL) at any time point. The results for the Ti groups were consistent with the results of Nothdurft et $\mathrm{al}^{33}$; in both studies, higher cell spreading was demonstrated on machined Ti surfaces and optimal proliferation on both surfaces. However, the proliferation results were different from those of Esfahanizadeh et al, ${ }^{36}$ who reported that the Laser-Lok groups had higher proliferation, possibly because of the different assay methods used for viability measurements and the differences in specimen preparation.

In the present study, the morphology of cells observed under SEM attached to laser-modified Ti and PEEK surfaces was different from that observed on nonmodified surfaces. On the laser-modified specimens, most cells were elongated, with more pseudopods attached in the grooves than the machined titanium and PEEK groups.

Cell morphology (elongated versus round cells) determines cell-surface affinity. ${ }^{33,36}$ Various surface modifications may cause changes in fibroblast morphology. Elongated cells have more cytoplasmic pseudopods, which results in stronger attachments to surfaces ${ }^{36}$ Laser ablation technology is used to create a series of cellsized ( 8 to $11 \mu \mathrm{m}$ ) circumferential channels with optimal size for cell attachment. ${ }^{36}$ Microgroove surface structure increases the contact area and enables the integration of cell pseudopods and collagen microfibrils with the surface. ${ }^{37}$

In the studies by Esfahanizadeh et al $^{37}$ and Ricci and Alexander, ${ }^{38}$ SEM revealed that the majority of cells in the Laser-Lok group were elongated and had pseudopods, while in the titanium group, a combination of elongated and round cells was observed on the surfaces. The SEM results in the present study were consistent with those of former studies. ${ }^{36,38}$ For the PEEK laser-modified specimens, the cells were elongated and attached into the grooves. For the PEEK laser- and plasma-treated surfaces, the quality and quantity of the fibroblast attachments were improved. On the non-laser-modified surfaces, the cells had a combination of elongated and round shapes. Studies on the biological (cell attachment and proliferation) characteristics of laser-modified PEEK surfaces to compare with the results of the present study are lacking.

Different laser texturing and combinations of different surface treatments should be investigated further. The results of the present study demonstrated that PEEK implant components were comparable with Ti in many aspects and, in some specific treatment situations, may be a better choice.

\section{Conclusions}

Based on the findings of this in vitro study, the following conclusions were drawn: 
1. Laser-modified titanium and PEEK surfaces led to improved, guided gingival fibroblast attachment when compared with non-laser-modified surfaces.

2. Plasma treatment of PEEK materials increased the wettability of this polymer and improved the proliferation of HGF.

3. Therefore, PEEK implant components may be a better clinical choice in areas of esthetic challenge, where maximum soft-tissue/implant component contact is essential. However, further in vivo evaluations of these materials are necessary to confirm this conclusion.

\section{Acknowledgments}

The authors thank BioHorizons and Invibio companies for providing the disks used in this study.

\section{References}

1 Y.S. Kim, Y. Ko, S.B. Kye, S.M. Yang. Human gingival fibroblast (HGF-1) attachment and proliferation on several abutment materials with various colors. Int J Oral Max Impl, 29 (2014), pp. 969-975

2 E. Rompen, N. Raepsaet, O. Domken, B. Touati, E. Van Dooren. Soft tissue stability at the facial aspect of gingivally converging abutments in the esthetic zone: a pilot clinical study. J Prosthet Dent, 97 (2007), pp. S119-S125

3 R.J. Lazzara, S.S. Porter. Platform switching: a new concept in implant dentistry for controlling postrestorative crestal bone levels. Int J Periodont Rest, 26 (2006), pp. 9-17

4 J.Y. Kan, K. Rungcharassaeng, T. Morimoto, J. Lozada. Facial gingival tissue stability after connective tissue graft with single immediate tooth replacement in the esthetic zone: consecutive case report. J Oral Max Surg, 67 (2009), pp. 40-48

5 J.K. Foong, R.B. Judge, J.E. Palamara, M.V. Swain. Fracture resistance of titanium and zirconia abutments: an in vitro study. J Prosthet Dent, 109 (2013), pp. 304-312

6 M.W. Klotz, T.D. Taylor, A.J. Goldberg. Wear at the titanium-zirconia implant-abutment interface: a pilot study. Int J Oral Max Impl, 26 (2010), pp. 970-975

7 M. Stimmelmayr, D. Edelhoff, J.F. Güth, K. Erdelt, A. Happe, F. Beuer. Wear at the titanium-titanium and the titanium-zirconia implant-abutment interface: a comparative in vitro study. Dent Mater, 28 (2012), pp. $1215-1220$

$8 \mathrm{~S}$. Hahnel, A. Wieser, R. Lang, M. Rosentritt. Biofilm formation on the surface of modern implant abutment materials. Clin Oral Implan Res, 26 (2015), pp. 1297-1301

9 X. Wang, T. Lu, J. Wen, L. Xu, D. Zeng, Q. Wu, et al. Selective responses of human gingival fibroblasts and bacteria on carbon fiber reinforced polyetheretherketone with multilevel nanostructured $\mathrm{TiO}_{2}$. Biomaterials, 83 (2016), pp. 207-218

10 J.E. de Val, G. Gómez-Moreno, C.P. Martínez, M.P. Ramírez-Fernández, J.M. GraneroMarín, S.A. Gehrke, et al. Peri-implant tissue behavior around non-titanium material: Experimental study in dogs. Annals of Anatomy-Anatomischer Anzeiger, 206 (2016), pp. 104-109

11 D.E. Smith, G.A. Zarb. Criteria for success of osseointegrated endosseous implants. J Prosthet Dent, 62 (1989), pp. 567-572

12 T. Albrektsson, D. Buser, S.T. Chen, D. Cochran, H. DeBruyn, T. Jemt, et al. Statements from the Estepona consensus meeting on peri-implantitis. February 2-4, 2012. Clin Implant Dent Relat Res, 14 (2012), pp. 781-782

13 T.O. Albrektsson, C.B. Johansson, L. Sennerby. Biological aspects of implant dentistry. Periodontol, 4 (2000), pp. 58-73

14 H. Siadat, M. Panjnoosh, M. Alikhasi, M. Alihoseini, S.H. Bassir, A.R. Rokn. Does implant staging choice affect crestal bone loss? J Oral Maxillofac Surg, 70 (2012), pp. 307-313

15 P.G. Coelho, J.M. Granjeiro, G.E. Romanos, M. Suzuki, N.R.F. Silva, G. Cardaropoli, et al. Basic research methods and current trends of dental implant surfaces. J Biomed Mater Res, 88B (2009), pp. 579-596 
16 D.M.D. Ehrenfest, P.G. Coelho, B.S. Kang, Y.T. Sul, T. Albrektsson. Classification of osseointegrated implant surfaces: materials, chemistry and topography. Trends Biotechnol, 28 (2010), pp. 198-206

17 R. Guarnieri, M. Serra, L. Bava, M. Grande, D. Farronato, V. Iorio-Siciliano. The impact of a lasermicrotextured collar on crestal bone level and clinical parameters under various placement and loading protocols. Int J Oral Maxillofac Implants, 29 (2014), pp. 354-363

18 V. Iorio-Siciliano, R. Matarasso, R. Guarnieri, M. Nicolò, D. Farronato, S. Matarasso. Soft tissue conditions and marginal bone levels of implants with a laser-microtextured collar: A 5-year, retrospective, controlled study. Clin Oral Implants Res, 26 (2015), pp. 257-262

19 R. Guarnieri, M. Grande, S. Ippoliti, lorio-SicilianoV, F. Riccitiello, D. Farronato. Influence of a Laser-Lok surface on immediate functional loading of implants in single-tooth replacement: Three-year results of a prospective randomized clinical study on soft tissue response and esthetics. Int J Periodont Rest, 35 (2015), pp. 865-875

20 R. Guarnieri, M. Grande, F. Zuffetti, T. Testori. Incidence of peri-implant diseases on implants with and without laser-microgrooved collar: a 5-year retrospective study carried out in private practice patients. Int J Oral Max Impl, 33 (2018), pp. 457-465

21 M.A. Listgarten, N.P. Lang, H.E. Schroeder, A. Schroeder. Periodontal tissues and their counterparts around endosseous implants [corrected and republished with original paging, article originally printed in. Clin Oral Implants Res, 2 (1991), pp. 1-19

22 P. Schupbach, R. Glauser. The defense architecture of the human peri implant mucosa: A histological study. J Prosthet Dent, 97 (2007), pp. s15-s25

23 M. Degidi, A. Piattelli, A. Scarano, J.A. Shibli, G. lezzi. Peri-implant collagen fibers around human cone Morse connection implants under polarized light: A report of three cases. Int J Periodont Rest, 32 (2012), pp. 323-328

24 M. Nevins, D.M. Kim, S.H. Jun, K. Guze, P. Schupbach, M.L. Nevins. Histologic evidence of a connective tissue attachment to laser micro- grooved abutments: A canine study. Int J Periodont Rest, 30 (2010), pp. 245255

25 M. Nevins, M.L. Nevins, M. Camelo, J.L. Boyesen, D.M. Kim. Human histologic evidence of a connective tissue attachment to a dental implant. Int J Periodont Rest, 28 (2008), pp. 111-121

26 S. Kim, K.C. Oh, D.H. Han. Influence of transmucosal designs of three one-piece implant systems on early tissue responses: A histometric study in beagle dogs. Int J Oral Max Impl, 25 (2010), pp. 309-314

27 B. Chehroudi, T.R. Gould, D.M. Brunette. Titanium-coated micro- machined grooves of different dimensions affect epithelial and connective-tissue cells differently in vivo. J Biomed Mater Res, 24 (1990), pp. 12031219

28 H. Wang, M. Xu, W. Zhang, D.T. Kwok, J. Jiang, Z. Wu, et al. Mechanical and biological characteristics of diamond-like carbon coated poly aryl-ether- ether-ketone. Biomaterials, 31 (2010), pp. 8181-8187

29 D.M. Brunette, B. Chehroudi. The effects of the surface topography of micromachined titanium substrata on cell behavior in vitro and in vivo. J Biomech Eng, 121 (1999), pp. 49-57

30 J.C. Rodriguez, T. Koticha, D.L. Eubanks, I. Rudek, F.J. Molz, L. Chiavaccini, et al. Influence of microtextured implant surfaces on peri-implantitis and its treatment: a preclinical trial. Int J Oral Max Impl, 33 (2018), pp. 51-57

31 C.K. Akkan, M. Hammadeh, S. Brück, H.W. Park, M. Veith, H. Abdul-khaliq, et al. Plasma and short pulse laser treatment of medical grade PEEK surfaces for controlled wetting. Mater Lett, 109 (2013), pp. 261-264

32 K. Webb, V. Hlady, P.A. Tresco. Relative importance of surface wettability and charged functional groups on NIH 3 T3 fibroblast attachment, spreading, and cytoskeletal organization. J Biomed Mater Res, 41 (1998), pp. $422-430$

33 F.P. Nothdurft, D. Fontana, S. Ruppenthal, A. May, C. Aktas, Y. Mehraein, et al. Differential behavior of fibroblasts and epithelial cells on structured implant abutment materials: a comparison of materials and surface topographies. Clin Implant Dent R, 17 (2015), pp. 1237-1249

34 D. Quéré. Wetting and roughness. Annu Rev Mater Res, 38 (2008), pp. 71-99 
35 D.K. Sarkar, M. Farzaneh, R.W. Paynter. Superhydrophobic properties of ultrathin rf-sputtered Teflon films coated etched aluminum surfaces. Mater Lett, 62 (2008), pp. 1226-1229

36 N. Esfahanizadeh, S. Motalebi, N. Daneshparvar, N. Akhoundi, S. Bonakdar. Morphology, proliferation, and gene expression of gingival fibroblasts on Laser-Lok, titanium, and zirconia surfaces. Laser Med Sci, 31 (2016), pp. 863-873

37 S. Weiner, J. Simon, D.S. Ehrenberg, B. Zweig, J.L. Ricci. The effects of laser microtextured collars upon crestal bone levels of dental implants. Implant Dent, 17 (2008), pp. 217-228

38 J. Ricci, H. Alexander. Cell response to surfaces: a concise summary. Int J Periodont Rest, 36 (2016), pp. s39s46 